\title{
T. S. Eliot's Spiritual Journey in Designing The Cocktail Party as a Drama of Conversion
}

\author{
Gül Kurtuluş \\ Bilkent University
}

\begin{abstract}
In his quest for spiritual fulfillment, Thomas Stearns Eliot conducts a meticulous religious study which teaches him distinctive interpretations of human existence and their various functions that they are supposed to assume in the world. Eliot's personal attachment to religious knowledge and his reflections of religious studies inevitably manifest themselves in his literary works; be it his dramas or poems, mostly in the forms of philosophical and psychoanalytical analysis of his characters and the detected problems observed in their relationships. The Cocktail Party, a play starting off as a drawing-room comedy soon converts to a serious analysis of human psychology and the nature of human interactions. While engaging with these particular points, the play offers possibilities to discuss several religious allusions, though dealt with subtly. Integrated with religion, characters' attitudes towards a given situation and their final decision position them in their quest either in "hypothetical" enlightenment or in a "supposed" repetition of a vicious circle. The enforcing power behind the play is interestingly a psychiatrist, who adds dynamism and mystery to the plot and has a special task in making the play a drama of conversion. The inner conflicts of the characters which ultimately lead to a series of problems in their relationships are the main concern which causes the characters search for different solutions. Accordingly, they make their own choices to cease their inner struggles. This paper aims to explore the concept of conversion in Eliot's The Cocktail Party with references to the playwright's religious journey in his literary career.
\end{abstract}

Keywords: T. S. Eliot, drama of conversion, verse drama, modern poetic drama, Buddhism

T. S. Eliot's The Cocktail Party goes through a surprising transformation in its literary form early in the play. Set in the drawing room of Chamberlaynes' London flat, the work craftily represents itself as a potential comedy play. Thus, during the first few pages, it is possible to read it as a conventional drawing-room comedy. The change, however, is immediately recognized. The play soon converts its form to a more modern structure with darker themes handled with serious treatment. This transformation takes the work to a new realm where there is no one truth or one possible solution for an inner problem. In this sense, the new form is more compatible with modernism, which likes to explore the abstract, the unknown, and the unconventional. Accordingly, the alteration in the form in fact arranges a new field for the work where the theme of religious conversion can be discussed in a more satisfactory way. Seemingly Eliot believes that between religion and literature, there is an undeniably peculiar relationship and that they are inescapably affecting one another. His statements suggest that literary works should pose existential questions examining the divine aim of the

Gül Kurtuluş, Dr., Department of English Language and Literature, Bilkent University, Turkey; main research field: Early Modern and Modern Drama, English and American Short Fiction, Early Modern Diplomacy and Correspondence. 
universe (just like Eliot who has gone this process of conversion himself, trying to attain meanings to life and humanity), to which religions and theologies are supposed give fulfilling explanations. According to his theory, religion constitutes such a big part of literary criticism that without it, any criticism would be insufficient. In his essay entitled "Religion and Literature," Eliot asserts "In ages like our own, in which there is no such common agreement (on ethical and theological matters), it is the more necessary for Christian readers to scrutinize their reading, especially of work of imagination, with explicit ethical and theological standards. The greatness of literature cannot be determined solely by literary standards" (Jasper Detweiler, 10). Eliot's preoccupation with the integration of Eastern thought into his play might be uncanny to his Western readers due to its mysticism and content, but then again it provides them with new standards among which they are meant to select the one that suits them best. Eliot, as his character Reilly, presents different standpoints on a crossroad, if you will, and the reader is meant to scrutinize their reading according to their own religious preferences. Hence, interestingly enough, the reader is also expected to either convert his religious standards or continue to hold his old beliefs. As the playwright of religious conversion, Eliot acknowledges his own inadequacies, though and do not claim a mastership on Eastern philosophies. He has his own concerns about bringing the unknown to Western cultural mentality, a point that his instructor at Harvard, Irvin Babbitt, is also skeptical of. From the article entitled "T. S. Eliot and Buddhism," we learn that Eliot says "A good half of the effort of understanding what Indian philosophers were after - and their subtleties make most of the great European philosophers look like school boys - lay in trying to erase from my mind all the categories and kinds of distinction common to European philosophy from the time of the Greeks" (McCarthy, 35). Eliot's fear of a possible failure removes him from his European/American roots at least while he is engaging in the particularities of the philosophy and incorporating those in Western understanding. Thus, he continues his arguments by saying "My only hope of really penetrating to the heart of that mystery would lie in forgetting how to think and feel as an American or a European" (McCarthy, 35). Such kind of an attempt suggests, if not all the time, at least for a time being, he goes through a transition in his self so as the playwright, he experiences a temporary but powerful conversion to understand the Eastern philosophy to the furthest extent possible. Therefore, it can be concluded that the process of conversion is applicable to the book, the characters, the reader and the playwright himself in a striking way. Nevertheless, it is noteworthy to mention again that there is no underlined specific hierarchy between religious theologies (not only between Eastern and Western philosophies but also among Christian sects) and no explicit religious labels on characters. There are only different means with different ends, each of which would take us distinctive realities. Eliot in his book Christianity and Culture also puts forward that the suggestion of Christianity's superiority over any non-Christian theology would be just as wrong as any suggestion favoring these "new religions," as he puts it. Thus, he comes to a conclusion by saying "Any religion, while it lasts, and on its level gives an apparent meaning to life, provides a framework for a culture, and protects the mass of humanity from boredom and despair" (Eliot, 106). It is possible, then, to say Eastern philosophical approaches give Eliot's work new meanings and further aesthetic qualities, also gives further pleasure to its readers.

\section{The Journey to the Soul}

In the light of the things discussed above, it can be claimed that Eliot's meditation on both Christian theologies and Eastern philosophies have affected his imaginative works in the first place in a positive way, because they have succeeded in elaborating his narration with a whole new understanding of existential issues, 
which might be challenging to his Western readers, but still quite mind-expanding. The integration of Eastern thought adds further dimensions to the play and the character's personalities and life. The process of conversion, on the other hand, is applicable to the work, its creator and characters and lastly to a certain extent to Eliot's readers. As the playwright of the drama of conversion, what Eliot is doing is not to be a Christian or Buddhist missionary. The process of conversion in The Cocktail Party is a part of his spiritual journey, through which he is able to speculate more on religious issues and make new experiments on his themes and writing. Eliot's engagement in religious conversion is not quite understandable on the surface meaning most of the times, though; it is rather dealt quite subtly and by implication, which makes it open to different interpretations.

Eliot's religious journey perhaps stems from the desire to challenge his own self and his writing in order to take his intellectual faculties to another level by giving it an insight. As he is familiarizing himself with different spiritual dimensions, he begins to bring his characters into his journey and gives their existences new forms and meanings. Eastern philosophy, in this sense, helps him to meditate on the different understandings of the world and humankind. It is possible to see this meditation in The Cocktail Party through the development of the character named Celia. More than any other character, Celia succeeds to examine the life she happens to be leading and she eventually achieves a supposed awakening. That awakening, however, does not simply cause a sense of regret which one can get rid of through confession, but it rather requires the constant involvement of the practitioner in the quest for a further enlightenment. The suggestion of the play is that Celia's realization, thanks to the cracking of her lover's marriage, brings about her conversion to some unexpected religious practices. Celia can definitely be regarded as a Christian martyr due to the references to her crucifixion at the end of the book, but her spiritual journey seems also applicable to the teachings of Eastern philosophy and contains Buddhist elements. Through her quest, Christian theologies and Buddhist teachings have been brought together, and thanks to Eliot's religious meditations, the distinctions are highlighted, whenever necessary. For instance, unlike most of the conventional Christian practices, Eastern philosophies seem to require more severe practice and attachment on individuals' part.

Being a Buddhist required deep reflection on scriptural texts so that one was able to understand the deeper message behind them and figure out how to incorporate the message into one's daily existence. It is not the kind of religion where a person can listen to a sermon once a week' says Lindsay Sarin in her statements while describing the two religions. (Sarin, 3)

The necessity for an active participation in Buddhist thought instead of an unsatisfactory level of attention is the main reason why Eliot attempts to bring Celia closer to Eastern philosophy and it definitely paves new ways for the play, because through this character, Eliot incorporates his personal theological studies with the play. With the help of her newly attained perspective, Celia completes what Eliot presumably cannot find in Christian theological movements, particularly in Unitarianism, from which he converts. Accordingly, it would not be just if we were to say that Eliot seeks a more serious treatment of human existence only in his life. Parallel to what is argued here, Sarin continues to comment on Eliot's use of Eastern philosophy and religious patterns by saying "Eliot's work and criticism demanded this kind of absolute engagement so it would make sense that this would extend to other areas of his life. Eliot saw faith as sustaining and did not see this kind of spiritual fulfillment in the world around him" (Sarin, 3). Whether Christian theologies fall short in spiritual fulfillment or not is a controversial issue for our part, but it is obvious that Eliot is in search of a more assertive and deeper realization of the self and the world with the help of religion, whether it is a Christian or Buddhist one. 
Within the framework of our argument, the unidentified guest that turns out to be a psychiatrist later in the play is one of the key characters that can be analyzed related to the drama of conversion. Sir Henry Harcourt-Reilly encourages those who are in need of "help" to choose between different paths, each bringing about different consequences. In the article entitled "Reality and Its Double in T. S. Eliot's The Cocktail Party" by Sarah Bay-Cheng, it is argued that Reilly is the necessary substitution for a spiritual guide like Buddha in the following words: "Sir Reilly must be seen as a mentor Buddha figure, with Julia and Ales (the other two 'Guardians') serving the function of Bodhisattvas, those on the path to Nirvana who take on the task of helping others" (Bay-Cheng, 5). Surely, Celia is not the only person who Reilly attempts to lead to an insight. Edward Chamberlayne and his runaway wife, Lavinia are also in close contact with the psychiatrist. However, the guidance of Reilly does not work for every character in the same way, which underlines the importance of self-will and discovery during the process of conversion. Lavinia and Edward are so much concerned with the inadequacies of each other that they do not bother to reflect on their own selves, an attitude Eliot is critical of. Celia, on the other hand, comes to appreciate her own being and solitude. It is interesting to notice that the turning point for Celia and her appreciation of non-attachment are derived from the problems in her lover's ${ }^{1}$ marriage. She says "I mean that what has happened has made me aware that I've always been alone. That one always is alone. Not simply the ending of one relationship, not even simply finding that it never existed-but a revelation about my relationship with everybody" (Eliot, Act II, 133). During their ongoing conversation, Celia first confesses her emotions about her current psychological situation to Reilly just as Lavinia and Edward previously do. The concept of confession is significant, because it implicates the awareness of the problem. However, going deeper in the realm of the problem is another issue and perhaps needs further courage. Edward and Lavinia, despite seeing their problem, stop their quest in the middle of the journey and ignore the underlying implications of their problems. Thus, they are supposedly condemned to experience the repetition or similar versions of what they have been gone through and complaining about. The point is that they do not want to be cured, rather they simply learn to tolerate and pretend, which is nothing but continue to conform to the world's known old ways. Accordingly, their conversion is not fulfilled according to Eliot's perspective. A repetition of their former unsatisfactory lives is what they consider as the rebirth of their relationship, though. Reilly's description of the other path, however, is more compatible with what Eliot is trying to attain during his own life-time and what he explores in his quest. Reilly says "The second (way) is unknown, so requires faith-the kind of faith that issues from despair. The destination cannot be described; you will know very little until you get there; you will journey blind. But the way leads towards possession of what you have sought for in the wrong place" (Eliot, Act II, 141). Reilly in this statement draws a distinction between these two worlds, each being represented with different religious attitudes. Even so, he is not antagonistic in his treatment of religious affairs, not explicitly favoring one path over the other, nor is he presenting Eastern-like philosophies as the anti-thesis of Christianity. He is not advocating this unknown world because nobody really knows what it bears for its immigrants. Even those who are acting as spiritual guardians, including Reilly who is supposed to have a satisfactory vision of this alternative world, cannot really explain how it really feels when one is converging his/her way. Only when they try it themselves, can they feel the real sense of conversion. Thus, Julia says to Reilly "You and I don't know the process by which the human is trans-humanized: What do we know of the kind of suffering they must undergo on the way of illumination?" (Eliot, Act II, 147) The reference to the idea of trans-humanization is noteworthy on the grounds that it is also related to conversion; a reference to the conversion of the human form, and thus to a large extent the conversion of identity, as well. 


\section{Christianity and Buddhist Allusions in Eliot's The Cocktail Party}

The Cocktail Party embodies the distinctive features of T. S. Eliot's own beliefs which were firstly formed through his Unitarian family and environment, influenced later in his youth by his studies of Buddhism at Harvard and finally by his conversion to Anglicanism in 1928. Premiered in 1949, The Cocktail Party, therefore, is more than a drawing room comedy; it has the characteristics of the drama of conversion, written by a playwright of religious conversion. In the play, the issue of conversion emerges as a consequence of the necessity in one's reconcilement with himself/herself and the satisfaction he/she receives from his/her actions. The inner conflicts of the characters which ultimately lead to a series of problems in their relationships towards one another are the main concerns which cause the characters to search for solutions and to make their own choices so as to cease their struggles in life. However, they do not follow the same paths while they are searching for their redemption which is the point that allows us to divide the characters into two: the one who chooses to return from their salvation Edward Chamberlayne and Lavinia Chamberlayne and the one who risks being lost for the sake of finding the aim of her existence in the world and her salvation, Celia Coplestone. There is another character who has an utmost importance in analyzing above named characters as he acts as a guide for these characters in their paths to salvation; it is the unidentified guest who appears to be the psychotherapist Sir Henry Harcourt-Reilly later in the play. Reilly's suggestion of two paths to salvation can be analyzed both from a Christian point view as Daven Michael Kari performs in T. S. Eliot's Dramatic Pilgrimage and Carol H. Smith in T. S. Eliot's Dramatic Theory and Practise, and from a Buddhist perspective as Sarah Bay-Cheng employs in her article entitled "Reality and Its Double in T. S. Eliot's Cocktail Party." Thus, this research essay is intended to examine the play in the lights of these works by discussing the two perspectives - the Christian and the Buddhist — with their applicability to the play.

Looking from the Christian point of view, Smith initially defines the two possible ways to salvation in Christianity in his work:

In the history of Christian mysticism from the time of the writings... there have traditionally been two paths by which the soul could come to God - the Negative Way and the Affirmative Way. Followers of the Negative Way believe that God may be reached by detaching the soul from the love of all things that are not God... The Way of Affirmation, on the other hand, consists of the recognition that... everything in the created world is an imperfect image of Him. Thus, all created things are to be accepted in love as images of the divine. (Smith, 57-58)

In Eliot's play both of these Ways are to be found in an intertwined form; in that, the Affirmative Way is clear by the representation of the Christian marriage of the Chamberlaynes and the Negative Way is present in Celia's path to martyrdom.

The play opens with Edward's dilemma over the abandonment of his wife with whom he has intra-marital quarrels for a long time. Much to his surprise, he is suffering from her wife's leaving. His surprise arises from the fact that he formerly thought he was in love with Celia, thus he is supposed to be happy with his wife's leaving. However, Edward does not have a clear mind to make such a judgement because he is not sure either about his feelings or his personality. This indecisive and weak side of Edward is revealed to him by the unidentified guest to whom Edward keeps saying he wants his wife back. The unidentified guest who appears as the conscience of Edward in the first act determines that Edward does not want the woman he loves but he wants his own personality. His identity is on the reflection of his wife and by losing her, Edward has actually lost himself, which is the very reason of his uneasiness about his situation in the first act as the unidentified 
guest explains this to Edward as follows "There's a loss of personality; or rather, you've lost touch with the person you thought you were" (Eliot, Act I, line 29). Edward, though, cannot see the point that he is defining his identity through the existence of Lavinia at this level. He naively believes that he is in love with his wife and that is the reason why he wants her back. Reilly gets Lavinia to return to Edward only to prove that Edward is wrong. Having her back does not resolve Edward's dilemma but to make matters worse Edward realizes his disillusionment that Lavinia is just a requirement in his life to help him from his identity and indeed he is incapable of loving anybody. Only when he reunites with his wife, can he realize this fact and decide to visit a psychotherapist who appears to be Reilly. Edward has already diagnosed himself and says to Reilly "I am not afraid of the death of the body, but this death is terrifying. The death of the spirit" (Eliot, Act II, 113). Apparently he has lost his belief in himself as a person with a soul. To him, his spirit is dead and, unable to cope with this problem; he demands to be cured by being put into a sanatorium. However, Reilly convinces him that the solution for this problem is not to be found in a sanatorium but in Lavinia because Lavinia, by leaving Edward, has led up to Edward's self-realization that he is supposed to have a spirit and to love somebody so as to form his identity and make sure there is a reason for his existence in the world. Edward's ultimate decision to continue to live not alone in a sanatorium but with Lavinia forms the basis of Smith's discussion regarding the principles of the Affirmative Way in the old Christian mysticism. In order to find out what he really is as Reilly puts it, Edward needs to know the very reason of his existence in the world which suggests his relationship to the creator. "Only by acknowledging that he is fundamentally defined by his relationship to the creator can the creature discover any stable ground for identity" (Smith, 168). This explains the rationalization of Edward's choice of continuing to live with Lavinia: Lavinia is the created that is used as a means by Edward to find his personality and accordingly reach reconciliation and salvation. As Reilly suggests without your personality "You feel no longer quite human; You're suddenly reduced to the status of an object-a living object but no longer a person" (Eliot, Act I, scene I, 29), and in order not to feel as an object Edward's personality requires Lavinia.

While Edward's problem is concerned with his inability to love somebody, that of Lavinia has its source in her incapability of being loved. When the couple faces at Reilly's office, the psychotherapist explains that Lavinia is deceiving herself and others from the beginning that she is prostrated because her husband has been cheating on her. The actual reasons behind her prostration, though, have to do with her recognition that her lover, Peter loved Celia instead of her. "You had wanted to be loved; you had come to see that none had ever loved you. Then you began to fear that no one could love you" (Eliot, Act II, 124). Therefore, similar to Edward, Lavinia proves to be a lover of self and a self-deceiver and is suffering from the same isolation. In other words, the isolation of Lavinia is caused by the absence of her self-knowledge just like Edward. She is forced to recognize it by means of Reilly and reconcile both with herself and her husband and achieving this leads to the fading of her uneasiness and salvation. In order to reach salvation, though, she has to learn to forgive. Back in the second act, upon her return Lavinia informs Edward of her hope in a change in his personality "I thought there might be some way out for you if I went away. I thought that if I died to you... you might be able to find the road back to a time when you were real" (Eliot, Act I, scene III, 97-98). She regards herself as already reformed and she is resenting her husband for being the same as always. However, what she has to learn is the nature of Reilly's advice that "What we know of other people is only our memory of the moments during which we knew them. And they have changed since then" (Eliot, Act I, scene III, 71). The significance of this assertion is not merely the fact that people are constantly changing but the necessity that they should be 
accepted as if they were newborn, forgiven for past deficiencies and given chance to prove themselves as anew. Thus, the salvation of Lavinia requires her forgiveness of Edward which “... parallels Christ's conclusion that those who refuse to forgive others will not be forgiven by God, thus alienating them from hope on earth and in heaven" (Kari, 51). Finally, Lavinia understands that she can reach the comfort of Christian love and fellowship only by means of the continuation of her marriage to Edward and that is why she decides to have Edward in her life which proves that Lavinia, just like her husband, prefers to follow the Affirmative Way. By forgiving Edward, she can find her identity, reconcilement, salvation and accordingly her love of God.

Much like the Chamberlaynes, Celia experiences alienation and its consequences, but Celia is different from the Chamberlaynes; in that, she does not believe that her salvation is in this ordinary world or the ones in it which are the imperfect reflections of God according to the Affirmative Way. In contrast, she has already begun a quest for values above the physical world even before she visits psychotherapist Reilly as a patient. "Everyone's alone — or so it seems to me, they make noises and think they are talking to each other; they make faces and think they understand each other. And I'm sure that they don't" (Eliot, Act II, 134). Celia's disillusionment does not merely arise from her losing Edward but from her awareness that any kind of real relationship whether this is love or not is not possible in the outer world as people perceive it. People believe mistakenly that they love, value and need each other; nevertheless, all those feelings are fake and humanity consists of lonely individuals. Some people somehow come to realize this feeling of loneliness at some point in their lives like the Chamberlaynes. This recognition makes life unbearable and they feel the necessity to find a way to cope with this suffering and one way is "to maintain (oneself) by the common routine, learn to avoid excessive expectation, become tolerant of (oneself) and others, giving and taking, in the usual actions what there is to give and take" (Eliot, Act II, 139). This quotation suggests that the moment of awareness of loneliness recedes at one point and is "remembered as an interval of painful intensity" and is replaced with "a sense of relief that one again enters the everyday world" (Smith, 175). This suggests the principles of the Affirmative Way which is the path chosen by the Chamberlaynes. The Negative Way, on the other hand, "is unknown and so requires faith - the kind of faith that issues from despair... You will journey blind. But the way leads towards possession of what you have sought for in the wrong place" (Eliot, Act II, 141). Celia prefers to follow the Negative Way because her speech to Reilly reveals her natural depth and growing insight, the features that differentiate her from the Chamberlaynes. Celia comes to the recognition of her loneliness as a result of her disappointment over Edward and her statements illustrate that she is intended to search for reconcilement and peace for her soul in a journey which forces her to be alienated from her environment. "Through Reilly's advising (and prodding), she comes to discover her need for the Negative Way of self-denial and loneliness, the solitary way of and toward the crucified self' (Kari, 56). Celia's setting out on a journey to Kinkanja and her way to crucifixion allude to the certain norms of Christian doctrine. First of all, she connects the reason of starting this unknown and lonely journey to her feeling of guilt which she names as "a sense of sin" (Eliot, Act II, 134). Her feeling of guilt is certainly originated from her self-realization that she herself has created the object of her love in the shape of Edward and has deceived herself and caused the break-up of a couple with this illusion. "It's the feeling of... emptiness, or failure towards someone, or something, outside of myself; and I feel I must... atone-is that the word?" (Eliot, Act II, 137) Her sense of guilt or sin is clearly corresponding to the Christian doctrine of atonement. Her being crucified in Kinkanja for the sake of the Christian natives of the region while she is on duty as a nurse is a direct allusion to the crucifixion of Christ. In addition to this, her name is an abbreviation for Saint Cecilia (Kari, 53), which implies that she is destined to be 
a saint. Thus, Celia favors the Negative Way and aims at directly reaching the love of God on her own. "Celia has chosen to conduct her love affair with God rather than to be content with the reflection of God's love in the love of creature for creature" (Smith, 173).

As Smith and Kari discuss in their works, Christian elements and influences are clear during the processes of salvation of the mentioned characters. Nevertheless, looking from another perspective unveils various other implications behind the actions of the characters. As mentioned earlier, Eliot studied Buddhism at Harvard, which has its effects on his works as Bay-Cheng suggests in her article. In-depth analysis of the play shows that she touches on certain correct points. To continue with Celia, Bay-Cheng regards her more as a one who follows "the path of Buddhist enlightenment than that of Christian salvation" (Bay-Cheng, 4). Her awareness of the unreality of the world and her suffering parallel with the belief in Buddhism describe the world and the things in it as "intangible" and "impermanent" (Bay-Cheng, 4). According to Buddhism, the only way to get rid of all the artificiality of the world as one perceives it can only be achieved through isolation which is the exact thing performed by Celia. She leaves her London home for the sake of "houseless land of Kinkanja" (Bay-Cheng, 5). Although such certain points regarding the process of Celia's salvation are corresponding to Buddhist elements, it would be wrong to characterize her as a Buddhist saint as her ending up with being crucified suggests that she dies as a Christian saint.

\section{Conclusion}

If Celia's self-questioning of the world and path to isolation shares some similarities with the Buddhist belief, Edward and Lavinia represent "the attachment to delusion" (Bay-Cheng, 5) according to Buddhist point of view. By choosing to stay in the dark and to learn to tolerate the unrealities of life rather than reveal and face them as Celia decides to perform, they appear to live happily ever after at the end of the play as a re-united couple. However, Buddhist perspective suggests another more plausible alternative that "If Edward and Lavinia have been reborn to each other, it is clearly not a Christian baptism, in which they are renewed, or born again, but a Buddhist rebirth in which they are condemned to repeat their lives once again" (Bay-Cheng, 6). The conversation between Edward and Lavinia over the party that they are about to throw at the very end of the play supports this point "Edward: And for the party. Lavinia: Now for the party. Edward: It will soon be over. Lavina: I wish it would begin. Edward: There is the doorbell. Lavinia: Oh! I'm glad. It's begun" (Eliot, Act III, 190). The cocktail party has a metaphorical meaning and the repetitions refer that the relationship of the Chamberlaynes is doomed to witness the couple's previous conflicts. Contrary to the ending of Celia, that of the Chamberlaynes suggests that the Buddhist perspective works more convincingly here; in that, the Chamberlaynes are clearly to be destined to experience same problems related to their marriage in the future, which cannot be associated with true Christian salvation of a marriage. Christian elements appear in their process of saving their individual existence and their marriage through one another, as discussed earlier, but apparently these elements may not sustain its impact in saving their marriage in future.

To sum up, The Cocktail Party conveys the origins of Eliot's own belief of Christianity and the effects of Buddhism on his way of believing. The marriage of Edward and Lavinia is rescued thanks to the Christian values such as Edward's preference to reach the creator through the created or Lavinia's forgiveness of Edward. However, the prospective future of their marriage does not suggest Christian salvation but the acknowledgement of conducting a fake relationship for the sake of the individual happiness of the couple. On the contrary, Celia's process of self-questioning and her path to salvation involves some Buddhist elements, but 
she proves to be a true Christian saint by sacrificing herself while she is helping the Christians in Kinkanja. Thus, Eliot reflects his own belief of Christianity and his interest and appreciation of Buddhist way of believing through the major characters of The Cocktail Party, which qualifies the play as a play of conversion.

\section{Notes}

1. All references to the play are from T. S. Eliot's The Cocktail Party: A Comedy. New York: Harcourt Brace, 1978.

\section{Works Cited}

Abel, Lionel. Tragedy and Metatheatre. Ed. Martin Puchner. New York: Holmes and Meier, 2003. 133-5.

"Anti-theatre." The Penguin Dictionary of Literary Terms and Literary Theory. Ed. J. A. Cuddon. 3rd ed. UK: Penguin Books, 1992.

Arrowsmith, William. "Notes on English Verse Drama 11: The Cocktail Party.” T. S. Eliot: Critical Assesments. Ed. Graham Clarke. London: Christopher Helm, 1990. 383-97.

“About Buddhism.” Atishta (11th Century Tibetan Buddhist). <http://www.thebigview.com/buddhism/>.

Barrett, William. "Dry Land, Dry Martini.” T. S. Eliot: Critical Assesments. Ed. Graham Clarke. London: Christopher Helm, 1990. 373-7.

Bay-Cheng, Sarah. "Reality and Its Double in T. S. Eliot's The Cocktail Party (Critical Essay).” Yeats Eliot Review, 2005: 1-15.

Bayreuth, Richard Taylor. "Lyric Drama from Yeats and Eliot to Beckett and Pinter: Modernist Method and Technique." Forum Modernes Theater 3:2 (1988): 124-38.

Donoghue, Denis. The Third Voice Modern British and American Verse Drama. NJ: Princeton, 1959.

Eliot, T. S. Christianity and Culture: The Idea of a Christian Society and Notes towards the Definition of Culture. New York: Harcourt, Brace, 1960.

---. The Cocktail Party: A Comedy. New York: Harcourt Brace, 1978.

---. The Use of Poetry and the Use of Criticism. London: Faber and Faber, 1950.

Forster, E. M. "Mr. Eliot's Comedy.” Listener 43 (23 March 1950): 533.

Grant, Michael. T. S. Eliot: The Critical Heritage, Vol. 2. London: Routledge \& Kegan Paul, 1882.

Heilman, Robert B. "Alcestis and the Cocktail Party." Comparative Literature 5.2. Duke University Press, 1953. $<$ http://www.jstor.org/stable/1769183>. 17/12/2011 10:57.

Hoeper, D. Jeffrey. "Drama in the Early and Mid-Twentieth Century.” Drama. NY: Macmillan, 1994. 801-6.

Jasper, David and Robert Detweiler. Religion and Literature: A Reader. 11 Jan. 2016. $<$ http://books.google.com.tr/books?id=klIvP2b510wC>.

Kari, Daven Michael. T. S. Eliot's Dramatic Pilgrimage: A Progress in Craft as an Expression of Christian Perspective. Lewiston: N.Y., 1990.

Koch, Vivienne. "Program Notes on the Cocktail Party." Poetry Quarterly 11.4 (Winter 1949): 248-51.

Malamud, Randy. T. S. Eliot's Drama: A Research and Production Sourcebook. New York: Greenwood, 1992.

McCarthy, Harold E. “T. S. Eliot and Buddhism.” Philosophy East and West 2.1 (1952): 31-35.

Misra, K. S. Twentieth Century English Poetic Drama: A Revaluation. New Delhi: Vikas, 1981.

Mishra, L. N. "Eliot as a Dramatist." Studies on T. S. Eliot. Ed. A. N. Dwivedi. New Delhi: Bahri Publications, 1989. 68-87.

Morgan, Arthur E. Tendencies of Modern English Drama. NY: Libraries Press, 1969.

Murry, John Middleton. “Mr. Eliot's Cocktail Party.” Fortnightly, December 1950: 391-8.

Pinion, F. B. "The Family Reunion to the Elder Statesman.” A T. S. Eliot Companion: Life and Works. London: MacMillan, 1986.

Sarin, Lindsay. "Full Circle: T. S. Eliot's Quest for Spiritual Fulfillment." Senior Honors Theses. 2008. Paper 189. $<\mathrm{http}$ //commons.emich.edu/honors/189>.

Sri, P. S. "Upanishadic Perceptions in T. S. Eliot's Poetry and Drama." Rocky Mountain Review 62. 2. Rocky Mountain Modern Language Association: 2008. <http://www.jstor.org/stable/20479528>. 17/Jan/2016. 
Smith, Carol H. "Eliot's 'Divine' Comedies: The Cocktail Party, The Confidential Clerk and The Elder Statesman.” A Companion to T. S. Eliot. Ed. David E. Chinitz. UK: Wiley-Blackwell, 2009.

Thouless, Priscilla. Modern Poetic Drama. USA: Ayer Publishing, 1968.

Williams, Raymond. "T. S. Eliot." Culture and Society. London, 1780-1950. 1958. T. S. Eliot's Dramatic Theory and Practise. Princeton: Princeton UP, 1963. 14

Shaw-Taylor, Desmond. "The Edinburgh Festival-1." T. S. Eliot: Critical Assesments. Ed. Graham Clarke. London: Christopher Helm, 1990. 359-61.

Smith, Carol H. “'Divine' Comedies.” A Companion to T. S. Eliot. Ed. David E. Chinitz. UK: Wiley-Blackwell, 2009. 253-5.

Walker, Julia A. "Why Performance? Why Now? Textuality and the Rearticulation of Human Presence." The Yale Journal of Criticism 16.1 (Spring 2003): 149-75. <http://muse.jhu.edu/journals/yale/summary/v016/16.1walker.html>. 